\title{
Media and Political Propaganda; Radio Cairo in the Era of Sadat: Analytical Study
}

Hijab EM*, Murad K, AI Badri HA and Ismael HK

Faculty of Media, Middle East University, Jordan

\begin{abstract}
The purpose of this study to examine the role of Radio Cairo as propaganda and political persuasion tools for Egypt's foreign policy in the era of President Sadat.

The study used content analysis as a research tool to examine how the Egyptian media used propaganda techniques in communicating messages to the Arab audiences in the Middle East in issue regarding Egypt's leadership in the peace process; the right of the Palestinian people for a national homeland; and Israel's right to exist. The Arabic materials and the scripts of Radio Cairo programming during three- weeks used for analysis.

Egyptian media concentrated mainly on six major techniques in communicating their messages to the Arab people regarding the Camp David agreements and the separate peace treaty with Israel, which included the following: Focusing Attention or Spotlighting; Testimonial, Division and Name calling; Self-Interest or Ad Hominem; Omission of Material; and Bandwagon.

The study concluded that, Radio Cairo had notable success in affecting the audiences and public opinion therein The majority of Egyptian people greeted Sadat's decision to visit Israel and the Camp David Agreements with relief and approval. They hailed Sadat as the "Peace Hero" and the "Savior of the Masses". Radio Cairo also played a highly important role in bringing the people of the Middle East, including the Israel's, closer to peace by stimulating positive thinking. Finally, Radio Cairo helped to make Israel for the first time, acceptable to the Arabs, particularly the moderate Arab states and to the Egyptian people themselves.
\end{abstract}

Keywords: Radio Cairo; Propaganda; President Sadat; Communication; People; The Camp David Summit Conference

\section{Introduction}

Radio is a medium of communication used to promote animosities and start wares among people; influencing and mobilizing the mass for revolution in the Middle East as in the era of President Nasser. The same medium used to promote friendships, peace with Israel and treaties of good will in the area. Radio Cairo did the latter in the era of President Sadat, as attested to by Camp David Agreements, Radio Cairo helped to make Israel acceptable to the Arab's, particularly the moderate Arab states, and to the Egyptian people.

\section{Objective}

The purpose of this study is to explain and examine the role of Radio Cairo in the peace process in the Middle East during President Sadat era.

\section{Study questions}

The study will examine and explain the role of Radio Cairo in the peace treaties during President Sadat. The study will answer the following questions:

What was the role of Radio Cairo as a vehicle of propaganda and political persuasion in the peace process in the Middle East in the era of President Sadat?

What are the strategies, tactics, techniques and principles of propaganda were employed to justify the Camp David Agreements and the separate peace treaty with Israel.

\section{Study important}

This study is an analytical study examines the role of Radio Cairo as a tool of political persuasion and propaganda in the Middle East in the era of President Sadat; it hoped that the study will provide adequate answers to the presiding questions.

\section{Literature Review}

\section{Egyptian radio}

Egyptian Radio also known as the Egyptian Radio's General Program transliterated as El-Bernameg Al-Aam, also popularly known as Radio Cairo is the pioneering Egyptian radio station that started broadcasting on 31 May 1934 in agreement with the Marconi Company.

In December 1947, the contract with Marconi was suspended in favor of an Egyptian national broadcasting station.

The station is known also for its call "This is Cairo. It is considered the First Program (in Arabic) of the (Egyptian Radio and Television Union).

The station had some of the best known Arab broadcasters of their time. Later on three main new radio channels were added, namely the pan-Arab the Voice of the Arabs in 1953, Egyptian Radio's Second Program in 1957 and the pan-Arab Middle East Radio in 1964. All four stations broadcast on high powered medium wave transmitters covering most of the Middle East and North and East Africa.

*Corresponding author: Hijab EM, Faculty of Media, Middle East University, Jordan, Tel: +962 6479 0222; E-mail: hijab1952@yahoo.com

Received January 02, 2018; Accepted Janaury 25, 2018; Published January 27 2018

Citation: Hijab EM, Murad K, Al Badri HA, Ismael HK (2018) Media and Political Propaganda; Radio Cairo in the Era of Sadat: Analytical Study. J Mass Communicat Journalism 8: 360. doi: 10.4172/2165-7912.1000360

Copyright: ( 2018 Hijab EM,et al. This is an open-access article distributed under the terms of the Creative Commons Attribution License, which permits unrestricted use, distribution, and reproduction in any medium, provided the original author and source are credited. 


\section{President sadat}

Muhammad Anwar el-Sadat was the third President of Egypt, serving from 15 October 1970 until his assassination by fundamentalist army officers on 6 October 1981. Sadat was a senior member of the Free Officers who overthrew King Farouk in the Egyptian Revolution of 1952, and a close confidant of President Jamal Abdel Nasser, under whom he served as Vice President twice and whom he succeeded as President in 1970.

In his eleven years as president, he changed Egypt's trajectory, departing from many of the political and economic tenets of Nasserism, re-instituting a multi-party system, and launching the Infitah economic policy. As President, he led Egypt in the Yom Kippur War of 1973 to regain Egypt's Sinai Peninsula, which Israel had occupied since the SixDay War of 1967, making him a hero in Egypt and, for a time, the wider Arab World. Afterwards, he engaged in negotiations with Israel, culminating in the Egypt-Israel Peace Treaty; this won him and Israeli Prime Minister Menachem Begin the Nobel Peace Prize, making Sadat the first Muslim Nobel laureate. Though reaction to the treaty-which resulted in the return of Sinai to Egypt - was generally favorable among Egyptians, it was rejected by the country's Muslim Brotherhood, which felt Sadat had abandoned efforts to ensure a Palestinian state. With the exception of Sudan, the Arab world and the Palestine Liberation Organization (PLO) strongly opposed Sadat's efforts to make a separate peace with Israel without prior consultations with the Arab states. His refusal to reconcile with them over the Palestinian issue resulted in Egypt being suspended from the Arab League from 1979 to 1989 . The peace treaty was also one of the primary factors that led to his assassination.

\section{Propaganda}

Propaganda is information that is not objective and is used primarily to influence an audience and further an agenda, often by presenting facts selectively to encourage a particular synthesis or perception, or using loaded language to produce an emotional rather than a rational response to the information that is presented [1]. Propaganda is often associated with material prepared by governments, but activist groups, companies and the media can also produce propaganda.

Propaganda is a modern Latin word, the gerundive form of propagare, meaning to spread or to propagate, thus propaganda means that which is to be propagated (Oxford dictionary). Originally this word derived from a new administrative body of the Catholic church (congregation) created in 1622, called the Congregation de Propaganda Fide (Congregation for Propagating the Faith), or informally simply Propaganda [2]. Its activity was aimed at "propagating" the Catholic faith in non-Catholic countries [2].

From the 1790s, the term began being used also to refer to propaganda in secular activities [2]. The term began taking a pejorative or negative connotation in the mid-19th century, when it was used in the political sphere [2].

In the twentieth century, the term propaganda has been associated with a manipulative approach, but propaganda historically was a neutral descriptive term $[1,2]$. A wide range of materials and media are used for conveying propaganda messages, which changed as new technologies were invented, including paintings, cartoons, posters, pamphlets, films, radio shows, TV shows, and websites.

\section{The Camp David summit conference}

At USA President Jimmy Carter's invitation, Israel's Prime Minister
Begin and the Egyptian President Anwar el-Sadat joined President Carter at Camp David in a last-chance effort to break the dangerous stalemate and deadlock in the Middle East.

The Camp David Conference started on the $5^{\text {th }}$ of September and ended on the $17^{\text {th }}, 1978$. After thirteen days at Camp David, Egypt's President Sadat and Israel's Prime Minister Begin signed two agreements [3]. The first agreement dealt with overall Mideast settlements - the West Bank and Gaza framework-; the second agreement was the Sinai Agreement and a plan for Egyptian-Israeli peace treaty [4].

The two agreements $r$ at Camp David represented an initial step toward a final peace settlement and involved only two parts in the Arab-Israeli conflict [5].

The Iraqi government circulated a memorandum calling for immediate joint Arab action against Sadat's "retreat is concession" in the Camp David "Framework for Peace" in the Middle East. Iraq viewed itself as an integral part of the eastern confrontation front with Israel. The Iraqi memorandum encouraged the Arab governments to take a serious and responsible position in order to prevent the implementation of the Camp David agreements, and invited them with the exclusion of Egypt - to an Arab summit conference hosted by Iraq. The rich Arab countries were requested to establish a national fund for catering to Egypt's financial needs and to the needs of all the Arab confrontation countries and Palestinian Liberation Organization (PLO), [6].

An Arab summit conference was held in Baghdad on November 2, 1978, and was attended by all invited Arab states. The declared objectives of the conference were to attempt to persuade and convince Sadat to re-join the Arab soldieries by forfeiting and surrendering his commitment to the Camp David Agreements, which were viewed as the unconditional humiliating surrender of the Arab cause and the Palestinians' rights [7]. In response to Camp David Accords, the Arab countries, particularly the radical non-moderate Arab states and PLO, could not endorse the accords and remained adamant, firm and unyielding in their refusal. They were convinced that the Israeli government would continue to push and intensify its settlement policies in the occupied lands, with a view toward their ultimate and eventual incorporation into Israel.

From the Arab view, Camp David constituted an abandonment of a comprehensive settlement in favor of a separate Egyptian-Israeli peace. This view was widely held in most of the Arab countries [8] They felt that Sadat had let them down by making a separate peace with Israel in exchange for the return of the Sinai Peninsula [9].

In summary, the Arab countries were convinced that the Camp David Accords represented only a separate peace agreement between Egypt and Israel, and that these agreements did not represent a just, durable, comprehensive peace settlement in the area [10].

During the Camp David Agreements, Egyptian broadcasters stood ready to propagate to the public their opinions concerning this matter. In the following section, the content of Radio Cairo's political broadcasts will be analyzed [11].

\section{Methodology and Procedures}

The study will use content analysis as a research tool to answer the study questions. The place of content analysis in communication research is indicated by the following paradigm for communication research: Who says what to whom with what effect [12]. 
The Arabic materials and the scripts of Radio Cairo programming during three- weeks used for analysis. The procedure for choosing the content of the programs includes the following:

Selecting the appropriate sampling of the daily and weekly political, news, talk shows and commentary programs purposively from the Program schedule of Radio Cairo's "Voice of the Arabs" programs.

Selecting the appropriate sample of the scripts of these programs randomly. The guiding principle in the sampling was to give every script of the sampling programs an equal chance of being drawn for the sample. The purposively selected programs were carried by the Egyptian political broadcasts between the first of August 1978 and the end of April 1979, the period which witnessed the Camp David Summit and the Camp David Accords between Egypt and Israel, which were signed on March 26, 1979.

The daily programs selected were:" Comments in the News"/15 minutes, which was run daily at the peak time period/1:40 PM, and repeated at 8:10 PM. The second program was "The Talk of the Press"/15 minutes, which was run daily at 8:45 AM. The third program was "Dialogue with Listeners"/5 minute programs, which was run at 10:45 PM. The name of the weekly program was "Arabs and the World"/30 minutes, which run at 10:30 PM every Monday [13].

Selecting the unit of analysis: The theme was considered (subject matter, statement, issues, argument, comments or any other selfcontained expression).

Constructing categories: A category system was used to classify the content of the preceding programs in order to identify the pertinent symbols. Such categories covered the full range of the content of the purposively selected sampling news and political-commentary programs.

The purpose of analyzing some of the news, commentary and political programs on "Voice of the Arabs" is to show the following:

The goals and objectives of the Egyptian news and political programs broadcast between the first of August 1978 and the end of April 1979.

\section{To whom those broadcast directed?}

What the major themes carried by the Egyptian political comments and news broadcast were?

What methods, strategies and techniques were employed by the Egyptian broadcasters to justify the Camp David Accords and the separate peace treaty with Israel, and to influence and affect public opinion, convincing and persuading the people in the Arab countries to support and champion the Egyptian imitative and Egypt's leadership in the peace process in the Middle East, and to win the minds and emotions of the masses for peace in the area [14].

\section{Data analysis}

The content analysis of the Egyptian political, commentary, and news that the Egyptian broadcasters concentrated on three major issues or themes, in communicating their messages to the Arab populations regarding the Camp David agreements and the separate peace treaty with Israel. These major themes could be divided as follows:

Egypt's leadership in the peace process.

The right of the Palestinian people for a national homeland.

Israel's right to exist.
The study will examine how the Egyptian media used propaganda techniques to deal with these issues in communicating their messages to the Arab audiences in the Middle East [15].

\section{Question 1: Egypt's leadership in the peace process}

The content analysis of the Egyptian political programs showed that Egypt was usually accorded a position of leadership and centrality which enhanced her capabilities; thus, Egypt as self-appointed leader in the Arab world, came to play a special role in the Middle East [16].

Radio Cairo confirmed that without Egypt, the Arabs could achieve no progress, politically, economically, or militarily, and could do nothing in the field of social and cultural development. Radio Cairo highlighted Egypt's central and leading position in the Arab world, pointing out that there could be no war or peace without Egypt in the Middle East. Radio Cairo insisted that Egypt was, indeed, the center from which the other branches were formed; Egypt was a vital and sure base for the Arab nation. The Egyptian political broadcasters moved to criticize the radical Arab leaders by saying that, insisted of supporting Egypt efforts to restore the occupied Arab territories, radical Arab states were denouncing the Egyptian actions as treason [17].

Egypt publicly demanded Israel's withdrawal from "every inch" of the occupied territory and self-rule in domestic affairs in the West Bank and Gaza and sought Israeli withdrawal from east Jerusalem. At the same time, Egypt called for the establishing a Palestinian entity on both the West Bank and the Gaza Strip. This was a historical truth and could be realized by all Arabs [18].

The programs kept criticizing and condemning the attitudes of the radical Arab leaders. Those leaders, who claimed that they were for peace and against war, were with the Palestinian settlement just in order to recognize Israel.

Egypt's media questioned those Arab leaders: "What had Egypt done than work toward peace, if you knew its position and its demands in the current negotiations at Camp David"?

The Egyptian media emphasize to the Arab audience that the Palestinian problem was the essence, the heart, and the crux of the conflict in the Middle East and Egypt will try to break the statement in the Middle East negotiation (referring to the Egyptian objective of helping the Palestinians to put an end to Israel's occupation of the West Bank and Gaza Strip), and "a bomb here or there will not going to liberate the land".

The political programs in Radio Cairo's "Voice of the Arabs" confirmed that the Palestinians had the right to participate in deciding their own future, and questioned "whether there other alternatives to the offered solutions". These alternatives will be discussed objectively.

The Egyptian rulers, in their endeavor to convince the other Arabs country of the necessity of establishing a comprehensive peace settlement for all parties in the area under Egypt's leadership, threw in all their efforts and talent. They indicated that the Camp David Agreement was a real step towards a comprehensive peace which recognized the rights of the Palestinian people. This was the main theme, and it was used on all possible occasions.

Egypt's radio broadcasters indicate that those who followed the Mideast peace talks at Camp David found Egypt's alone fighting in the battle for peace; meanwhile, Egypt's target was to achieve a comprehensive peace settlement in all parts of the Middle East area. The Egyptians ask why the rest of the Arab states did not expand any 
effort in this respect. The Egyptian media people emphasized that the agreements of Camp David were not a framework for peace solely between Israel and Egypt. This framework was a comprehensive settlement to establish a just and lasting peace in the Middle East according to the United Nations Resolutions 242 and 338.

The Egyptian confirmed that these resolutions had been accepted by the Arab states in the Rabat Conference of 1974. In other words, the agreement came as a fulfillment of what Arab leaders agreed to in the Arab summit conferences. It was not a partial or individual agreement. It was a framework for a comprehensive settlement to liberate the Golan Heights as well as the Sinai Peninsula and involved the liberation of the West Bank and Gaza strip.

During the negotiation in Camp David, Radio Cairo focused in Egypt's position as a representative of the Arab states; moreover, it geared toward the key issues of the settlement and maintained that these positions were identical with the Arab views and demands. Radio Cairo indicated that Egyptian positions in the current negotiations in Camp David were:

Total Israeli military withdrawal with Arabs sovereignty restored after five years;

A Palestinian entity linked to Jordan after that five-year period of transition to Palestinian control, unlimited right of return for Arab refugees;

Total Israeli withdrawal possibility for U.N peacekeeping forces, demilitarize zone;

All settlements on occupied land were illegal and obstacles to peace; and Israeli withdrawal from east Jerusalem with no division of the city.

The Egyptian media emphasized that in Egypt demanded a "total withdrawal" from the West Bank and Gaza Strip and the establishing of Palestinian entity. This phrase was repeatedly used by Cairo Radio which moved to give some details to highlight the Camp David Agreements, thus intensifying the image which made it stand out to the Arab masses in the Arab world.

The Egyptian media emphasized to the masses that these two agreements were the framework for the overall Mideast Settlement and a plan for an Egyptian-Israeli peace treaty.

The Egyptian media considered the Camp David Agreements a real step toward a comprehensive peace which would secure the rights of the Palestinian people. The Egyptian political media confirmed that autonomy "is the first step on the road to self-determination and statehood" for the Palestinian. These catch-phrases were the main theme in the Egyptian media and were repeatedly used by Cairo Radio's "Voice of the Arabs". These Concepts, the Egyptian media wished the audiences in the Middle East to retain were repeated to the point of saturation. Making a special effort to tune in predisposes the listener to pay more attention to it and to believe what they hear.

\section{The right of the Palestinian people for a national homeland}

The content analysis of the Egyptian Media political programs shows that Egypt called audiences to recognize the core of the problem "a national home for the Palestinian people". The Egyptian media intended to outline the issues dividing the Arabs and Israelis and to reiterate the Arabs" views that total withdrawal from the occupied territory and the creation of a Palestinian homeland were prerequisites for Mideast peace. The Egyptian media reminded the audiences of
Israel's right for self-determination 30 years ago and urged the Israel's to grant the same right to the Palestinians.

The Egyptian media emphasized that Egypt was insisting on "a total withdrawal from the West Bank, the Gaza Strip and the Golan Heights, and the establishing of a Palestinian entity". This phrase was repeatedly used by Radio Cairo. These words were key words which were used by Egyptian Media. Other phrases repeatedly used were: Egypt is insisting not to ignore ant rights of the Palestinian people.

Achievement of the fundamental rights of the Palestinian people and their rights to self-determination.

The right of Palestinian to establish their own state.

Radio Cairo made it clear, that a solution to the Palestinian problem was the key to any Middle East peace settlement. The Egyptian broadcasters emphasized that "the Palestinian should participate in the determinations of their own future'. On the grounds that there must be a resolution of the Palestinian problem and a homeland for the Palestinian as an integral part of the peace settlement envisaged, the words, "a homeland for the Palestinian people", were the key words in the Egyptian Campaign for peace in the Middle East. Radio Cairo made it clear, also, that without a solution to the Palestinian refugee problem, there could be no durable peace in the Middle East. Radio Cairo insisted on the recognition of the Arab Palestinian people as a national entity, with the right to self-determination in their part of the common homeland. This homeland could be independent or linked with Jordan. They would have the right to participate in deciding their own future. Radio Cairo contributed to Israel's recognition of the Palestinian people's right to participate in their own future and establishing a Palestinian entity in the West Bank and Gaza Strip linked to Jordan.

"The right of the Palestinian people in deciding their own future" was a phrase repeatedly used by Radio Cairo. The Egyptian political programs confirmed that the Camp Davis Agreement were a real step to a comprehensive peace which secured the rights of the Palestinian people and pointed out that autonomy "was the first step on the road to self-determination and statehood". As it stood, Radio Cairo had a difficult time trying to convince other Arab leaders that face-to-face negotiations did not sell out the Arab cause.

\section{Israel's right to exist}

Radio Cairo emphasized that Sadat's trip to Israel broke down the barriers of suspicion, fear, illusion, and misinterpretation that for so long had prevented the two neighboring from even discussing peace. In the strongest acknowledgement ever made by an Arab broadcast of Israel's right to exist, Radio Cairo welcomed the Israelis to live peacefully in this part of the world; "we welcome you in sincerity". The Egyptian broadcasts added that Egypt would accept all the international guarantees that Israel might demand. Radio Cairo moved to explain that the Arab states had rejected Israel in the past, refusing to meet its representatives, "but today, we agree to live with you". Israel had become a fait accompli recognized by the whole world. Radio Cairo insisted that Israel could have peace with justice and territory occupied during the Six-Day War that they recognized the "core of the problem, a national homeland for the Palestinian people'.

After the Camp David Agreements and the separate peace treaty, the Egyptian political programs confirmed that what had passed was the end of suffering, and what is coming is a new life.

Radio Cairo added, in one totally unexpected step, that Israel and 
Egypt had broken their diplomatic statement, adding a hopeful, new dimension to the search for peace in the entire Middle East. Radio Cairo made it clear that, after the establishing peace in the rejoin, nothing would be difficult, nothing would be impossible in relations between the Arabs and Israelis, on all levels and in all senses. But, as long as the war went on, as long as there were factors likely to lead to a new war, there was separation by blood, even though there may have been the best of intention and purest of thoughts.

After Sadat's visit to Israel on November 22, 1977, Radio Cairo sought to make Israel acceptable to the Arabs (Particularly the moderate Arab states and the Egyptian people) for the first time and contributed to the recognition of Israel's right to exist as a "fait accompli" in the area of the Middle East.

\section{The strategically techniques Egyptian media used regarding Camp David}

According to the particular situation, the message might be rational or emotional. Primarily, due to the high level of illiteracy in the Arab world, Egyptian media tended to follow the emotional approach. Nevertheless, whatever their content, propaganda messages were delivered through a variety of techniques.

In this case, the Egyptian media concentrated mainly on six major techniques in communicating their messages to the Arab people regarding the Camp David agreements and the separate peace treaty with Israel, which included the following.

\section{Focusing Attention or Spotlighting}

As it is graphically named, expedites perception by intensifying the image to make is stand out.

The Egyptian media effectively employed this technique in focusing attentions on Egypt's positions towards the key issues and towards the Camp David Agreements.

Radio Cairo praised Sadat's courage and imagination and continued to refute the agreements of the rejectionists, whose arguments, it proclaimed, were contrary to the truth; Egypt had not turned its back on the Arab world. On the other hand, it remained the vanguard of the Arab world and would continue the struggle for the Palestinians' rights and for their right of self-determination.

\section{Testimonial}

In this technique, the propagandist used an esteemed persons or political entity; in other words, the target was asked to believe something simply because some "authority" said it. For this technique, the Egyptian media used religious sanctions to affect public opinion in the Arab world.

Egypt's radio media gave as evidence verses from the Holy Quran, particularly this verse "If they incline to peace, incline thou also to it, and trust in Allah, he is the hearer, the knower". Even the Mufti of Egypt and the Rector of Al-Azhar were brought to the radio to assure Muslims in the Arab world that Islam approved of such peace settlements with Israel.

Cairo Radio also excerpts' from the speeches of President Sadat to the People's Assembly, in which he strongly defended the Camp David Agreements and the separate peace treaty with Israel.

Radio Cairo's reminded the audiences in the Arab world of Egypt's sacrifices and of how the Egyptian people sacrificed a lot and presented a lot for Palestinian.

\section{Division and Name calling}

This strategy aimed at splitting the country under attack into various antagonistic elements. This form of propaganda was directed by Radio Cairo against every other radical Arab country. Radio Cairo used the terms, "reactionary" and "feudalist" to describe the anti-Egypt leaders of the Arab world. Radio Cairo attached the Arab hard-liners and criticized their opposition. "Those who reject the peace reject the war too; they should know that the coast of peace is too high and should remember the coast of war". Those people were not interested in solving the problem of the Palestinian people.

At the same time, the "Voice of the Arabs" addressed the Arab leaders, starting that there was still a chance for all the Arabs to participate in the communing peace of the Mideast, implying that it would be a just, comprehensive and lasting peace. Radio Cairo urged the Palestinian to join in forthcoming talks on autonomous rule for the West Bank and Gaza, asking the Arabs to realize that demonstrations would not throw the occupation troops out of the land.

\section{Self-Interest or Ad Hominem}

This technique was so basic that some politicians stress it as the "primary" propaganda technique. The propagandist's theme is "See what we are doing for you". The Egyptian propagandists effectively employed this slogan, "We, the Egyptian people, realize that, we form an organic part of a greater Arab entity and are aware of our responsibilities and obligations towards the Arab Nation. Egypt is fighting alone in the battle for peace, while Egypt's target is to achieve a comprehensive peace settlement for all parts of the area, to liberate the Golan Heights as well as the Sinai Peninsulas, and the liberation of the West Bank as well as the Gaza Strip. Peace means stability and prosperity for the whole area. We should congratulate our self after thirty years of war and sufferance".

\section{Omission of material}

This is the other side of the "selection" coin. It is natural that human beings should want to hide their faults and weaknesses, particularly when they are anxious to make a good impression. Omission of materiel is a convenient way to forget everything unfavorable to the persuasion campaign.

\section{Bandwagon}

Radio Cairo assured the audiences that the opposition was marginal and disorganized.

Most broadcasts, which addressed the audiences and carried messages supporting the Egyptian imitative or attacking rival Arab leaders or government, contained such phrases as "everyone knows...", "you all believe...", "all people share...", and so forth. These phrases were usually made the focus of the message conveyed in order to add weight to its content.

"Everyone knows that Egypt is insisting not to ignore any rights of the Palestinian people; and everyone knows that without Egypt, the Arabs cannot achieve any progress in politically, economically and militarily issues, and can do nothing in the area of social and cultural development".

Media addressed the Arab audiences with such phrases as "You all believe that Egypt is working for the interest of the Arabs, particular audiences the Palestinian people". They addressed the Arab audiences in the Middle East, asking God to bless the efforts of peace...peace which meant stability and prosperity, for the whole area instead of the 
Citation: Hijab EM, Murad K, Al Badri HA, Ismael HK (2018) Media and Political Propaganda; Radio Cairo in the Era of Sadat: Analytical Study. J Mass Communicat Journalism 8: 360. doi: 10.4172/2165-7912.1000360

Page 6 of 6

destruction and blood. War caused only sorrow and destruction for all. In seeking peace, President Sadat was not leading, but following the Egyptian people. The Egyptian people came out very strongly in favor of the peace.

Cairo's appeal, directed more and more to the Arab elite and to the moderates, was in danger of being swamped, as far as the audiences were concerned, by the more strident revolutionary voices of those who remembered the pre-war success of Nasser's operation.

\section{Conclusion}

Persuasion is a powerful tool for the advancement of personal and national causes. The communicator as a persuader should enhance his credibility whenever possible. Modern propaganda is based largely on the effect of the spoken word. The power of speech is the most distinctly human faculty that man possesses and the spoken word is preferred to the printed, and should be wed whenever possible. The powerful Egyptian radio service used by Nasser to promote revaluation in other Middle East Arab countries where used by Sadat to inform Arab audiences of the relations behind Egypt's various agreements with Israel over the occupied territory during the 1967 War. They also attempted to justify and persuade the Arab audiences and the emotions of the masses for peace. In the era of President Sadat, Radio Cairo played a role dissimilar to that in the era of President Nasser.

Radio Cairo contributed significantly to the peace process, persuasion for peace in the region. It also conveyed to the Arab masses what is believed to be the persuasive rationales regarding Camp David and the peace process in the Middle East. In the era of President Sadat, Egyptian radio tended to reflect the changing international political orientations of the country more than any other Egyptian mass medium.

Egyptian Radio was used as a vehicle of propaganda for peace by Sadat's government. During that time, Radio Cairo and the "Voice of the Arabs" played their most difficult roles, for the first time, the "Voice of the Arabs" encountered a new communication challenge; it was "swimming against the current".

In the late 1970, the situation reversed and Radio Cairo was impelled to formulate a different strategy, part of this strategy was to clarify Egypt's policies, focusing on Egypt's national role in the peace process, and in the struggle for just, durable and comprehensive peace.

The other part of the strategy was to maintain the organic relationship between Egypt and the Arab masses to keep their trust in Egypt and peaceful political line regardless of the stands and positions that were taken by the Arab regimes against Egypt.

In Egypt itself, Cairo Radio had notable success in affecting the audiences and public opinion therein. The majority of Egyptian people greeted Sadat's decision to visit Israel and the Camp David Agreements with relief and approval. They hailed Sadat as the "Peace Hero" and the "Savior of the Masses".

Cairo Radio played a highly important role in bringing the people of the Middle East, including the Israel's, closer to peace by stimulating positive thinking.

Finally, Radio Cairo helped to make Israel for the first time, acceptable to the Arabs, particularly the moderate Arab states and to the Egyptian people themselves.

\section{References}

1. Smith, Bruce L (2016) "Propaganda", britannica.com. Encyclopedia Britannica Inc.

2. Brown BD (2011) Strategic Public Relations: Audience Focused Practice.

3. Bill, Jams (1979) Politics in the Middle East, Toronto: Little, Brown and Company.

4. Boyd D (1982) Broadcasting in the Arab world: a survey of radio and television in the Middle East. Temple University Press.

5. Bangneld M, Steven S (1981). Sadat Goes to Jerusalem: Television Themes and Agenda, in Television Coverage of the Middle East, Norwood, New Jersey: Ablex Publication Corporation.

6. Badley P (1981) The Camp David Peace Process, Grantham, N.H., Thompson and Reutter.

7. Dawisha Al (1978) Egypt in the Arab world: the elements of foreign policy.

8. Sadat A (1978) Speeches and Interviews on the Occasion of his Visit to Jerusalem, Cairo: Ministry of Information.

9. Paul B (1981) The Camp David Peace Process: A Study of Carter Administration Policies 1977-1980. Tompson and Rutter.

10. Cull N, Culbert D, Welch D (2003) Propaganda and Mass Persuasion: A Historical Encyclopedia, 1500 to the Present.

11. Cunningham SB (2002) The Idea of Propaganda: A Reconstruction. Westport, Conn.: Praeger.

12. Herman ES, Chomsky N (1988) Manufacturing Consent: The Political Economy of the Mass Media. New York: Pantheon Books.

13. Robert C(1998) Encyclopedia of Propaganda.

14. Jowett Garth S, Victoria O'Donnell (2014) Propaganda and Persuasion, 6th edition. California: Sage Publications.

15. Kerr, Malcolm H (1975) The Egyptian Peace in the Middle East, New York: State University of New York Press.

16. Randal M (2002) Propaganda \&the Ethics of Persuasion. Orchard Park, New York: Broadview Press.

17. Paul R (2000) Endless Propaganda: The Advertising of Public Goods. Toronto University of Toronto Press.

18. Paul R (2004) Weapons of Mass Persuasion: Marketing the War against Iraq Toronto: University of Toronto Press. 